\title{
A Use of the Gravity Model to Estimate the Residential Distribution of New Workers at a Large Nuclear Energy Center ${ }^{\dagger}$
}

\author{
Caryl R. Ersenkal and B. L. Dillman*
}

\begin{abstract}
INTRODUCTION
A nuclear energy center in South Carolina consisting of twelve 1,200 megawatt nuclear plants at a single location is currently the subject of environmental and socioeconomic analyses. The development impact of such a center can be expected to be substantial because of the very magnitude of the project, quite apart from the real or imagined risks to health and safety. An essential element of this analysis involves projection of the location of in-migrants prior to the actual plant construction, as the size of the construction force is expected to be too large for communities to absorb without severe strain on the schools and other public services they provide and on such private markets as that for housing.

In order to accurately assess the impact of a very large infusion of economic activity on levels of employment and income, it is necessary to determine the extent of the area from which the work force will be drawn. This paper involves one aspect of a larger study of total socio-economic impacts. It attempts to develop a model to determine the subareas from which the construction work force will be drawn and the areas in which new construction workers will locate.
\end{abstract}

\section{THE GRAVITY MODEL}

In-migrants to an area will consider two major factors in choosing a particular area in which to live. It is expected that a worker will tend to locate so as to minimize transportation cost, and at the same time, will be attracted to areas offering a wide range of public and private goods. Gravity models account for both of these variables by relating distance (a proxy for transportation cost) and population (an indicator of goods availability) to interactions between areas.

\footnotetext{
*The authors are, respectively, Graduate Research Assistant and Professor, Department of Agricultural Economics and Rural Sociology, Clemson University.

tPublished with the approval of the Director of the S. C. Experiment Station, Clemson University, Clemson, S. C., as Technical Contribution No. 1831.
} 
Gravity models have been employed previously in economic-demographic models to allocate project in-movers associated with the construction of power plants. Several have been based on surveys of worker commuting data in sparsely populated western areas (5) (8) (9) (13). Other work includes that carried out for Oak Ridge National Laboratory (1) and reports by the Wizard Development Group (14).

The gravity model was originally formulated in terms of Newtonian physics and later generalized to model such human interactions as transportation, migration and market sales area identification (3) (7) (11). The basic gravity model states that interaction between two bodies varies directly with a function of their masses and inversely with some function of the distance between them

$$
I_{i j}=G \frac{\left(P_{i} P_{j}\right)}{d_{i j}^{b}}
$$

where: $\quad I_{i j}=$ interaction between center $\mathrm{i}$ and center $\mathrm{j}$;

$\mathrm{P}_{\mathrm{i}}=$ population at center $\mathrm{i}$

$P_{j}=$ population at center $\mathrm{j}$;

$\mathrm{d}_{\mathrm{ij}}=$ distance between center $\mathrm{i}$ and center $\mathrm{j}$;

$\mathrm{G}=$ constant to be empirically determined; and

$\mathrm{b}=$ exponent on distance.

Many modifications of the basic gravity model are possible. For this study, a formulation which shows the population potential of the plant site $\mathrm{j}$ contributed by various subareas i was selected.

$$
\mathrm{Wkrs}_{\mathrm{i}}=\mathrm{G} \frac{\operatorname{Pop}_{\mathrm{i}}^{\beta_{1}}}{\operatorname{Dist}_{\mathrm{ij}}{ }^{\beta_{2}}}
$$

where: $\quad \mathrm{Wkrs}_{\mathrm{i}}=$ number of workers living in area $\mathrm{i}$;

$\mathrm{Pop}_{\mathrm{i}}=$ population in area $\mathrm{i}$;

Dist $_{\mathrm{ij}}=$ distance from area $\mathrm{i}$ to site $\mathrm{j}$;

$\beta_{1}=$ population elasticity to be estimated;

$\beta_{2}=$ distance elasticity to be estimated.

Parameters were estimated by transforming the equation into log form:

$$
\log \mathrm{Wkrs}=\alpha+\beta_{1} \log \left(\mathrm{Pop}_{\mathrm{i}}\right)-\beta_{2} \log \left(\text { Dist }_{\mathrm{ij}}\right)
$$

where: $\alpha=\log \mathrm{G}$ 
It is expected that the elasticity measures $\beta_{1}$ and $\beta_{2}$ will differ for the two types of workers under study, in-migrants or movers to the site, and nonmovers or current residents.

In distributing a given number of workers, TOTAL, throughout a second region $\mathrm{B}$, the parameters $\alpha, \beta_{1}$, and $\beta_{2}$ are applied to data concerning population and distance for subareas of $\mathrm{B}$. To develop an estimate of workers from each subarea i in B,

$$
{ }_{\mathrm{B}} \mathrm{Wkrs}_{\mathrm{i}}^{\prime}=\alpha+\beta_{1} \log \left({ }_{\mathrm{B}} \mathrm{Pop}_{\mathrm{i}}\right)+\beta_{2} \log \left({ }_{\mathrm{B}} \text { Dist }_{\mathrm{ij}}\right) .
$$

To insure that the total workers allocated throughout B is equal to TOTAL, the estimate of ${ }_{\mathrm{B}} \mathrm{Wkrs}$ i is normalized such that,

$$
A_{i}=\frac{{ }_{B} W_{k r s}^{\prime}}{\sum_{i=1}^{n}{ }_{B} W_{k r s}^{\prime}}
$$

where $A_{i}$ represents the proportion of workers allocated to area i. The actual number of workers distributed to each $\mathrm{i}$ is

$$
{ }_{\mathrm{B}} \mathrm{Wkrs}_{\mathrm{i}}=\left(\mathrm{A}_{\mathrm{i}}\right)(\mathrm{TOTAL})
$$

A very comprehensive review of literature on the gravity model has been compiled by Hua and Porell (6). The reader desiring more detailed explanations is referred to this work.

\section{THE DATA}

The data utilized in this study were gathered by Duke Power Company by means of a construction worker survey at the Catawba Plant in York County, S. C. (12). The survey included information on place of residence, family size, distance traveled to work, and whether the worker had relocated when he was employed at the Catawba plant. The data were then aggregated by zip code of residence and classified by movers and non-movers.

The data in such a form are especially useful since they provide a basis upon which to estimate the spatial distribution of workers at similar types of construction sites. Since the data were available by zip code, they could be matched to specific towns, county census divisions (CCDs) and counties, and thus related to the Census of Population data available for such areas. Certain discrepancies were identified when commuting distance reported by workers were compared with the distances later estimated by engineers, and observations were eliminated when these differences were greater than $30 \%$.

After aggregating from the zip code level to the CCD and county level, a weighted average of distances traveled by all workers from each such area was 


\section{TABLE 1}

Gravity Model Applied to In-Movers ${ }^{\mathrm{a}}$ and Non-Movers ${ }^{\mathrm{b}}$ for Two Types of Subareas.

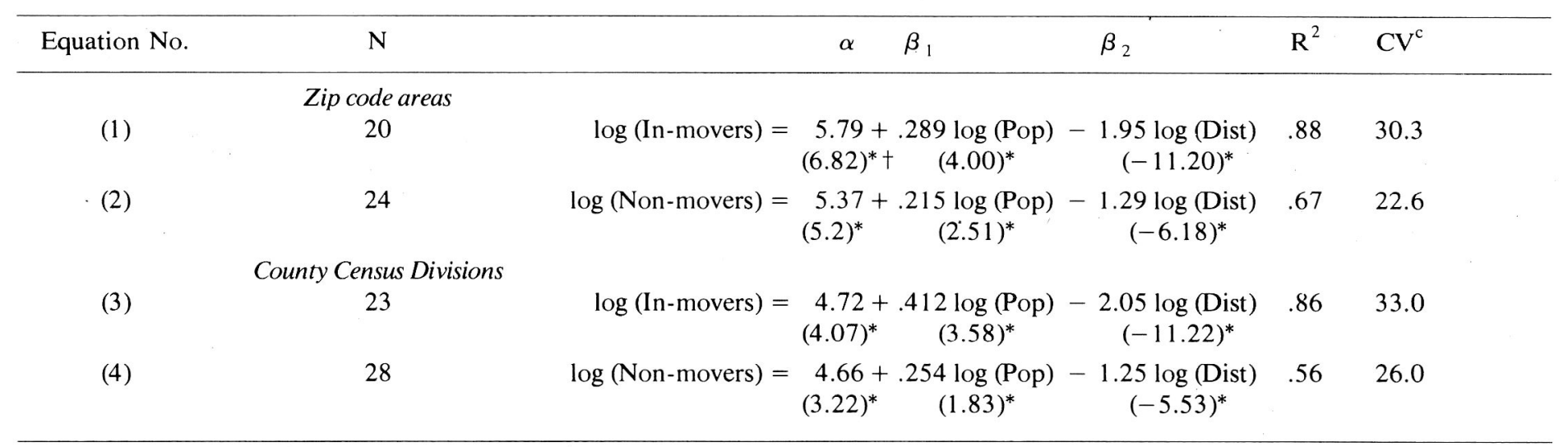

${ }^{\mathrm{a}}$ In-movers are defined to be employees that have moved their place of residence in order to work at the construction site.

bon-movers are construction workers from the region that did not move to work at the site but commute from their place of residence prior to their construction job.

${ }^{\mathrm{c}}$ Coefficient of variation

* Parameters are significant to the .95 level.

† Numbers in parentheses are values of Students' t. 
utilized as the commuting distance. Furthermore, CCDs and counties attracting fewer than six workers were excluded from the analysis because impact in such areas would be minimal.

\section{ANALYSES AND RESULTS}

Commuter patterns for non-mover and mover construction workers at the Catawba Plant were analyzed using the Duke Power Co. survey data. Table 1 presents the results of this analysis for both the zip code areas and for CCDs.

In each set of equations, a better fit, using this simple gravity model, was obtained for in-movers to the study area, than for non-movers. Both the absolute value of the distance and the population parameters are greater for in-movers than for non-movers. The higher distance elasticity indicates that new inmigrants are less willing to commute long distances than are current residents. This is expected since residents have social and economic ties to their current place of residence and would not be expected to move to the work site. In a similar manner, the higher population parameter in the in-mover equations indicates that they are more strongly affected by population size when making a residential decision, presumably because they are concerned with the increased availability of goods and services which a larger population represents.

Considerably less variation is explained when the model is applied to nonmovers, indicating that population and distance alone do not fully explain the distribution of non-movers. Other less readily quantifiable economic and social factors and events, some of which may be long forgotten, can be expected to play a more substantial role describing the spatial arrangement of non-movers.

The basic model was modified in several ways in an attempt to better explain this distribution. Various weights were applied to the population variable representing in and out of state locations. Dummy variables were created also to represent critical levels of population. The model presented above, however, consistantly provided the best fit with least variation.

The absence of any significant loss in accuracy and the similarity of parameter estimates in the zip code area model and the CCD model indicates that CCD level model is realistic and can be applied with no substantial loss in prediction ability. This is advantageous because of the general availability of data at the CCD level.

\section{APPLICATION TO ANDERSON COUNTY}

In order to distribute the estimated number of workers at the proposed Anderson County Nuclear Energy Center, the models developed for in-movers and non-movers using Catawba Plant data were applied using the procedure outlined earlier. It has been projected that 5,900 construction workers will be employed at the NEC in 1989, the peak year of construction (4). Sixty-five 


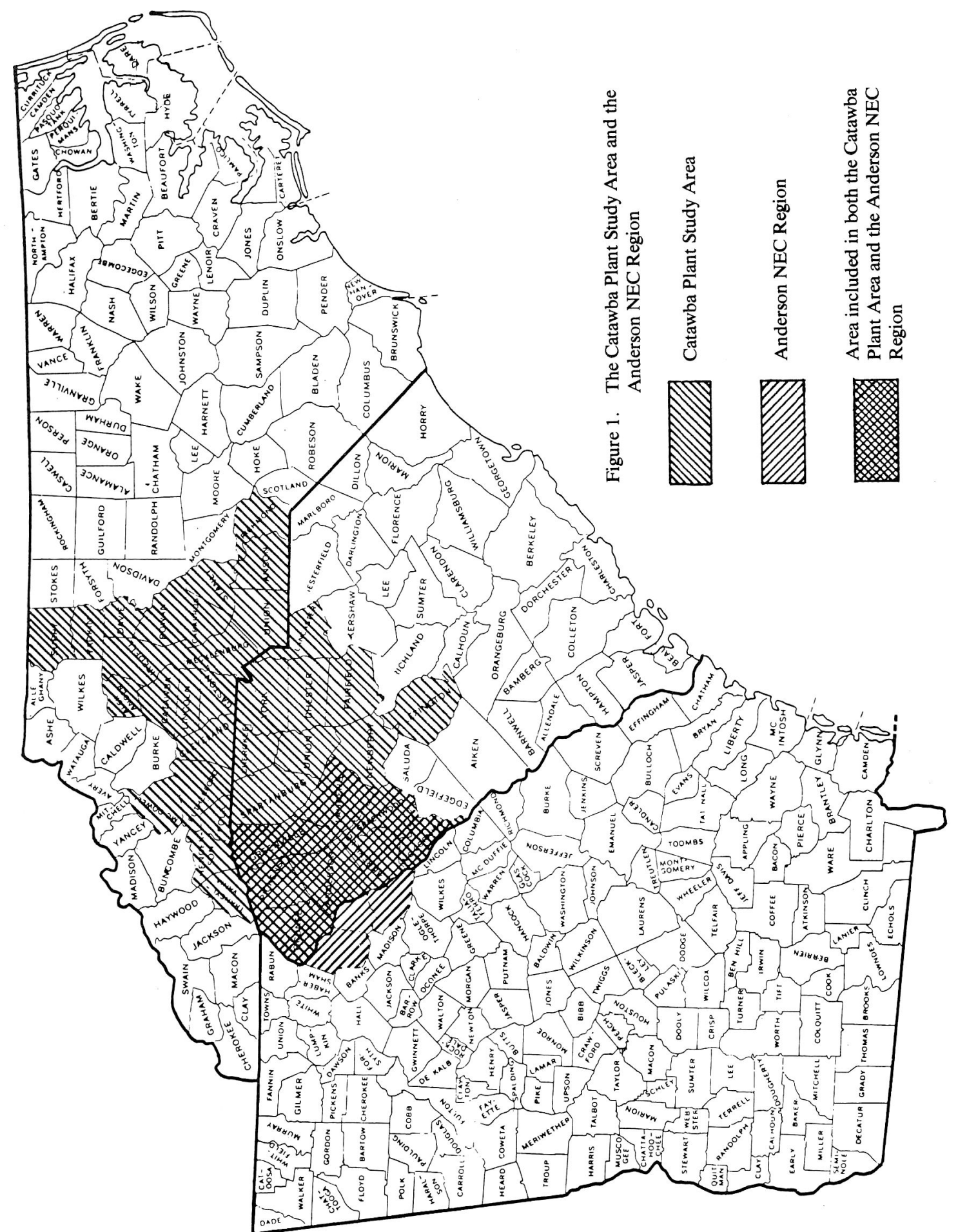


TABLE 2

Gravity Model Allocation of In-movers and Non-movers to CCDs in the Anderson NEC Region

\begin{tabular}{|c|c|c|c|c|c|c|c|c|}
\hline OBS & $\mathrm{CCD}$ & $\begin{array}{c}\text { CCD } \\
\text { Number }\end{array}$ & County & Distance & $\mathrm{IN}^{\mathrm{A}} \mathrm{i}$ & $\operatorname{NON}^{A_{i}}$ & In-Movers & Non-Movers \\
\hline 1 & Anderson & 1 & Anderson & 12.8 & 0.0547 & 0.0365 & 113 & 140 \\
\hline 2 & Anderson North & 2 & Anderson & 17.2 & 0.0187 & 0.0189 & 39 & 73 \\
\hline 3 & Anderson South & 3 & Anderson & 8.9 & 0.0940 & 0.0508 & 194 & 195 \\
\hline 4 & Belton & 4 & Anderson & 19.8 & 0.0112 & 0.0138 & 23 & 53 \\
\hline 5 & Belton East & 5 & Anderson & 22.2 & 0.0043 & 0.0076 & 9 & 29 \\
\hline 6 & Belton West & 6 & Anderson & 17.6 & 0.0132 & 0.0153 & 27 & 59 \\
\hline 7 & Brushy Creek & 7 & Anderson & 28.2 & 0.0055 & 0.0090 & 11 & 35 \\
\hline 8 & Fork & 8 & Anderson & 13.3 & 0.0160 & 0.0171 & 33 & 66 \\
\hline 9 & Honea Path & 9 & Anderson & 22.6 & 0.0095 & 0.0126 & 20 & 48 \\
\hline 10 & Iva & 10 & Anderson & 7.3 & 0.0822 & 0.0666 & 170 & 179 \\
\hline 11 & Pelzer & 11 & Anderson & 26.0 & 0.0058 & 0.0093 & 12 & 36 \\
\hline 12 & Pendleton East & 12 & Anderson & 19.8 & 0.0105 & 0.0133 & 22 & 51 \\
\hline 13 & Pendleton West & 13 & Anderson & 19.6 & 0.0103 & 0.0131 & 21 & 50 \\
\hline 14 & Starr & 14 & Anderson & 4.0 & 0.2591 & 0.0937 & 535 & 359 \\
\hline 15 & Williamston & 15 & Anderson & 24.3 & 0.0066 & 0.0100 & 14 & 38 \\
\hline 16 & Williamston Rural & 16 & Anderson & 22.2 & 0.0068 & 0.0102 & 14 & 39 \\
\hline 17 & Abbeville & 17 & Abbeville & 25.9 & 0.0083 & 0.0116 & 17 & 44 \\
\hline 18 & Amtre-Lowdesville & 18 & Abbeville & 14.0 & 0.0163 & 0.0173 & 33 & 67 \\
\hline 19 & Calhoun Falls & 19 & Abbeville & 21.8 & 0.0075 & 0.0109 & 16 & 42 \\
\hline 20 & Donalds & 20 & Abbeville & 23.8 & 0.0056 & 0.0091 & 12 & 35 \\
\hline 21 & Due West & 21 & Abbeville & 22.0 & 0.0075 & 0.0108 & 15 & 42 \\
\hline 22 & Conestee & 22 & Greenville & 36.4 & 0.0034 & 0.0067 & 7 & 26 \\
\hline 23 & Fountain Inn & 23 & Greenville & 39.6 & 0.0024 & 0.0053 & 5 & 21 \\
\hline 24 & Highland & 24 & Greenville & 36.7 & 0.0031 & 0.0063 & 6 & 24 \\
\hline 25 & Greenville & 25 & Greenville & 39.6 & 0.0075 & 0.0109 & 15 & 42 \\
\hline 26 & Greenville East & 26 & Greenville & 42.1 & 0.0041 & 0.0076 & 9 & 29 \\
\hline 27 & Greenville North & 27 & Greenville & 42.5 & 0.0039 & 0.0073 & 8 & 28 \\
\hline 28 & Greenville SWest & 28 & Greenville & 35.4 & 0.0077 & 0.0110 & 16 & 42 \\
\hline 29 & Greer & 29 & Greenville & 49.5 & 0.0024 & 0.0054 & 5 & 21 \\
\hline 30 & Paris & 30 & Greenville & 44.3 & 0.0029 & 0.0061 & 6 & 24 \\
\hline 31 & Piedmont & 31 & Greenville & 28.7 & 0.0059 & 0.0093 & 12 & 36 \\
\hline 32 & Riverside & 32 & Greenville & 42.3 & 0.0041 & 0.0076 & 8 & 29 \\
\hline
\end{tabular}




\begin{tabular}{|c|c|c|c|c|c|c|c|c|}
\hline OBS & $\mathrm{CCD}$ & $\begin{array}{c}\text { CCD } \\
\text { Number }\end{array}$ & County & Distance & $\mathrm{IN}^{\mathrm{A}_{\mathbf{i}}}$ & $\mathrm{NON}^{\mathrm{A}} \mathrm{i}$ & In-Movers & Non-Movers \\
\hline 33 & Simpsonville & 33 & Greenville & 38.8 & 0.0033 & 0.0065 & 7 & 25 \\
\hline 34 & Slater & 34 & Greenville & 48.5 & 0.0015 & 0.0040 & 3 & 16 \\
\hline 35 & Taylors & 35 & Greenville & 44.9 & 0.0027 & 0.0058 & 6 & 22 \\
\hline 36 & Tigerville & 36 & Greenville & 30.8 & 0.0036 & 0.0069 & 7 & 27 \\
\hline 37 & Travelers Rest & 37 & Greenville & 45.6 & 0.0024 & 0.0054 & 5 & 21 \\
\hline 38 & Woodville & 38 & Greenville & 29.3 & 0.0044 & 0.0078 & 9 & 30 \\
\hline 39 & Greenwood & 39 & Greenwood & 37.0 & 0.0055 & 0.0090 & 11 & 35 \\
\hline 40 & Greenwood East & 40 & Greenwood & 39.6 & 0.0020 & 0.0049 & 4 & 19 \\
\hline 41 & Greenwood North & 41 & Greenwood & 37.0 & 0.0030 & 0.0062 & 6 & 24 \\
\hline 42 & Greenwood West & 42 & Greenwood & 34.8 & 0.0036 & 0.0069 & 7 & 27 \\
\hline 43 & Hodges & 43 & Greenwood & 30.0 & 0.0053 & 0.0088 & 11 & 34 \\
\hline 44 & Kirksey & 44 & Greenwood & 47.8 & 0.0011 & 0.0033 & 2 & 13 \\
\hline 45 & Ninety-Six & 45 & Greenwood & 43.7 & 0.0022 & 0.0051 & 5 & 20 \\
\hline 46 & Troy & 46 & Greenwood & 30.5 & 0.0028 & 0.0060 & 6 & 23 \\
\hline 47 & Clinton & 47 & Laurens & 50.8 & 0.0026 & 0.0057 & 5 & 22 \\
\hline 48 & Cross Mill & 48 & Laurens & 44.0 & 0.0017 & 0.0044 & 3 & 17 \\
\hline 49 & Gray Court & 49 & Laurens & 40.8 & 0.0026 & 0.0057 & 5 & 22 \\
\hline 50 & Joanna & 50 & Laurens & 54.3 & 0.0011 & 0.0033 & 2 & 13 \\
\hline 51 & Laurens & 51 & Laurens & 43.7 & 0.0029 & 0.0061 & 6 & 23 \\
\hline 52 & Laurens Rural & 52 & Laurens & 41.4 & 0.0021 & 0.0049 & 4 & 19 \\
\hline 53 & Princeton & 53 & Laurens & 31.9 & 0.0037 & 0.0070 & 8 & 27 \\
\hline 54 & Watts Mills & 54 & Laurens & 45.2 & 0.0017 & 0.0045 & 4 & 17 \\
\hline 55 & McCormick & 55 & McCormick & 41.8 & 0.0023 & 0.0052 & 5 & 20 \\
\hline 56 & MT. Carmel & 56 & McCormick & 28.1 & 0.0033 & 0.0065 & 6 & 25 \\
\hline 57 & Parksville & 57 & McCormick & 51.1 & 0.0010 & 0.0031 & 2 & 12 \\
\hline 58 & Longcreek & 58 & Oçonee & 39.8 & 0.0015 & 0.0040 & 3 & 14 \\
\hline 59 & Mountain Rest & 59 & Oconee & 40.8 & 0.0013 & 0.0038 & 2 & 15 \\
\hline 60 & Oakway & 60 & Oconee & 22.1 & 0.0077 & 0.0110 & 16 & 42 \\
\hline 61 & Salem & 61 & Oconee & 37.8 & 0.0022 & 0.0051 & 5 & 20 \\
\hline 62 & Seneca & 62 & Oconee & 24.2 & 0.0078 & 0.0111 & 16 & 43 \\
\hline 63 & Seneca North & 63 & Oconee & 27.8 & 0.0047 & 0.0082 & 10 & 31 \\
\hline 64 & Seneca South & 64 & Oconee & 20.3 & 0.0106 & 0.0134 & 22 & 51 \\
\hline 65 & Walhalla & 65 & Oconee & 44.9 & 0.0018 & 0.0045 & 4 & 17 \\
\hline 66 & Walhalla North & 66 & Oconee & 41.6 & 0.0021 & 0.0031 & 4 & 19 \\
\hline 67 & Walhalla South & 67 & Oconee & 46.7 & 0.0014 & 0.0040 & 3 & 15 \\
\hline 68 & Westminster & 68 & Oconee & 27.5 & 0.0063 & 0.0098 & 13 & 38 \\
\hline 69 & Central & 69 & Pickens & 24.2 & 0.0072 & 0.0105 & 15 & 40 \\
\hline
\end{tabular}


TABLE 2 (continued)

\begin{tabular}{|c|c|c|c|c|c|c|c|c|}
\hline OBS & $\mathrm{CCD}$ & $\begin{array}{c}\text { CCD } \\
\text { Number }\end{array}$ & County & Distancę. & $I^{A} A_{i}$ & $\mathrm{NON}^{\mathrm{A}} \mathrm{i}$ & In-Movers & Non-Movers \\
\hline 70 & Clemson & 70 & Pickens & 22.0 & 0.0127 & $0.015 e$ & 26 & 58 \\
\hline 71 & Easley & 71 & Pickens & 33.6 & 0.0051 & 0.0086 & 11 & 33 \\
\hline 72 & Easley East & 72 & Pickens & 38.1 & 0.0020 & 0.0049 & 4 & 19 \\
\hline 73 & Easley Rural & 73 & Pickens & 31.1 & 0.0049 & 0.0084 & 10 & 32 \\
\hline 74 & Forest & 74 & Pickens & 46.5 & 0.0011 & 0.0034 & 2 & 13 \\
\hline 75 & Liberty & 75 & Pickens & 29.0 & 0.0050 & 0.0084 & 10 & 32 \\
\hline 76 & Pickens East & 76 & Pickens & 42.3 & 0.0018 & 0.0046 & 4 & 18 \\
\hline 77 & Pickens West & 77 & Pickens & 35.8 & 0.0038 & 0.0072 & 8 & 27 \\
\hline 78 & Six Mile & 78 & Pickens & 30.1 & 0.0046 & 0.0080 & 9 & 31 \\
\hline 79 & Bowman & 79 & Elbert & 19.1 & 0.0083 & 0.0115 & 17 & 44 \\
\hline 80 & Coldwater Creek & 80 & Elbert & 13.8 & 0.0158 & 0.0170 & 33 & 65 \\
\hline 81 & Elberton & 81 & Elbert & 18.2 & 0.0145 & 0.0162 & 30 & 62 \\
\hline 82 & Dove Creek & 82 & Elbert & 21.8 & 0.0062 & 0.0097 & 13 & 37 \\
\hline 83 & Middleton & 83 & Elbert & 18.4 & 0.0124 & 0.0147 & 26 & 56 \\
\hline 84 & Carnesville & 84 & Franklin & 26.6 & 0.0051 & 0.0085 & 11 & 33 \\
\hline 85 & Lavonia & 85 & Franklin & 19.6 & 0.0103 & 0.0131 & 21 & 50 \\
\hline 86 & Royston & 86 & Franklin & 20.8 & 0.0091 & 0.0121 & 19 & 47 \\
\hline 87 & Sandy Cross & 87 & Franklin & 27.2 & 0.0032 & 0.0065 & 7 & 25 \\
\hline 88 & Bowersville & 88 & Hart & 18.1 & 0.0088 & 0.0119 & 18 & 46 \\
\hline 89 & Hartwell N\&S & 89 & Hart & 19.0 & 0.0172 & 0.0180 & 36 & 69 \\
\hline 90 & Royston & 92 & Hart & 37.5 & 0.0020 & 0.0048 & 4 & 18 \\
\hline 91 & Broad River & 93 & Stephens & 26.4 & 0.0062 & 0.0097 & 13 & 37 \\
\hline 92 & Rock Creek & 94 & Stephens & 29.9 & 0.0050 & 0.0084 & 10 & 32 \\
\hline \multirow[t]{2}{*}{93} & Toccoa \& Toccoa Creek & 95 & Stephens & 28.9 & 0.0065 & 0.0099 & 13 & 38 \\
\hline & TOTAL & & & & 100.0 & 100.0 & 2065 & 3835 \\
\hline
\end{tabular}


percent of these, or 3,835 , are expected to come from the local labor force and the remaining 2,065 workers will be in-migrants.

Movers and non-movers were distributed to a twelve county region around Anderson County which includes 95 CCDs. Population figures for CCDs were obtained from the 1970 Census of Population and estimates of airline distance from the NEC site to the major town in each CCD were made using geographic coordinates.

The impact area, shown in Figure 1, was defined to include counties of residence for workers who commuted to Anderson County, S. C., according to commuting data from the 1970 Census of Population. It was assumed that a nuclear energy center in Anderson County will draw workers at least from those counties supplying labor to Anderson County as of 1970. Examination of the commuter patterns of Catawba Plant workers reveals that some workers were willing to travel distances of over 50 miles one way, thus, this 12 -county population estimate of the regional labor pool for a project of such magnitude is somewhat conservative.

The allocation of in-movers and non-movers to CCDs is presented in Table 2. For the purpose of comparison with 1970 Census commuter patterns to Anderson County (10), the results have been aggregated to the county level, and these are presented in Table 3. Based on a chi-square statistic calculated for the Catawba Plant data, it can be stated that the distribution of all commuters to York County is significantly different from the distribution of construction workers at the Catawba Plant. Thus, we can expect this will hold for workers at the Anderson NEC site as well, and we may generalize that application of the gravity model will yield a better estimate of construction worker locations than a regression-type projection of Census commuting data.

A major difference between commuting patterns for all types of workers in Anderson County and the pattern for NEC construction workers is that $92 \%$ of all workers in Anderson live in that county while only $38 \%$ of non-movers and $61 \%$ of in-movers are expected to live in Anderson County. A very similar pattern held true for the Catawba region as well, where $92 \%$ of all workers lived in York County with $42 \%$ and $65 \%$ of non-movers and in-movers, respectively, residing in the county.

In order to better compare general characteristics of the construction worker commuting patterns with those of all workers, a comparison of commuting patterns for construction workers and for all types of Anderson County workers is also presented in Table 3 . This includes the percentages of workers residing in each county outside of Anderson. Contrasting the allocations of in-movers and non-movers with all 1970 commuters reveals several general characteristics which appear to differ significantly.

As has been noted in similar studies, there is a tendency for both in-mover and non-mover construction workers to travel further to work than other types of workers (5) (8). Only $8.9 \%$ of 1970 commuters travel over 30 miles to work while $32.3 \%$ and $32.9 \%$ of in-movers and non-movers to the Anderson region are expected to do so. This of course, is partially because of the nature 
TABLE 3

Comparison of Commuting Patterns of Construction Workers to NEC with all Commuters to Anderson Co., 1970.

\begin{tabular}{|c|c|c|c|c|c|c|c|c|}
\hline \multirow[b]{2}{*}{ County } & \multirow[b]{2}{*}{$\begin{array}{c}1970 \\
\text { Population }\end{array}$} & \multirow{2}{*}{$\begin{array}{l}\text { Centroid } \\
\text { distance to } \\
\text { Anderson } \\
\text { centroid } \\
\text { (miles) }\end{array}$} & \multirow{2}{*}{\multicolumn{2}{|c|}{$\begin{array}{cc}1970 \text { Commuters } \\
\begin{array}{c}\text { Percent of total } \\
\text { living outside } \\
\text { Number } \quad \text { Anderson Co. }\end{array}\end{array}$}} & \multicolumn{4}{|c|}{ Projected NEC Workers } \\
\hline & & & & & $\begin{array}{l}\text { Number } \\
\text { in-movers }\end{array}$ & $\begin{array}{l}\text { Percent in-movers } \\
\text { living outside } \\
\text { Anderson Co. }\end{array}$ & $\begin{array}{c}\text { Number } \\
\text { non-movers }\end{array}$ & $\begin{array}{l}\text { Percent non-movers } \\
\text { living outside } \\
\text { Anderson Co. }\end{array}$ \\
\hline Abbeville, SC & 21,112 & 27.6 & 444 & 15.5 & 94 & 11.6 & 230 & 9.6 \\
\hline Anderson, SC & 105,474 & NA & 33,939 & - & 1,258 & - & 1,452 & - \\
\hline Elbert, GA & 17,262 & 30.3 & 51 & 1.7 & 119 & 14.7 & 266 & 11.1 \\
\hline Franklin, GA & 12,784 & 26.3 & 42 & 1.5 & 58 & 7.2 & 155 & 6.5 \\
\hline Greenwood, SC & 49,686 & 35.2 & 106 & 3.7 & 53 & 6.5 & 194 & 8.1 \\
\hline Greenville, SC & 240,546 & 27.1 & 916 & 32.0 & 136 & 16.8 & 464 & 19.4 \\
\hline Hart, GA & 15,814 & 19.8 & 365 & 13.1 & 58 & 7.2 & 134 & 5.6 \\
\hline Laurens, SC & 49,713 & 36.1 & 78 & 2.7 & 38 & 4.7 & 161 & 6.8 \\
\hline McCormick, SC & 7,955 & 47.1 & 18 & 0.6 & 14 & 1.7 & 58 & 2.4 \\
\hline Oconee, SC & 40,728 & 12.5 & 375 & 15.9 & 99 & 12.3 & 309 & 13.0 \\
\hline Pickens, SC & 58,956 & 25.6 & 454 & 0.2 & 100 & 12.4 & 305 & 12.8 \\
\hline Stephens, GA & 20,331 & 39.2 & 6 & 0.0 & 37 & 4.6 & 108 & 4.5 \\
\hline Total workers & & & 36,794 & & 2,065 & & 3,835 & \\
\hline \multicolumn{3}{|c|}{$\begin{array}{l}\text { Total workers residing } \\
\text { outside Anderson County }\end{array}$} & 2,855 & 100 & 807 & 100 & 2,383 & 100 \\
\hline \multicolumn{3}{|c|}{ Percent commuting over 30 miles } & & 8.9 & & 32.2 & & 32.9 \\
\hline \multicolumn{3}{|c|}{$\begin{array}{l}\text { Percent residing in counties } \\
\text { over } 100,000\end{array}$} & & 32.0 & & 16.8 & & 19.4 \\
\hline \multicolumn{3}{|c|}{$\begin{array}{l}\text { Percent residing in counties } \\
\text { between } 40,000 \text { and } 100,000\end{array}$} & & 35.4 & & 35.9 & & 40.7 \\
\hline \multicolumn{3}{|c|}{$\begin{array}{l}\text { Percent residing in counties } \\
\text { under } 40,000\end{array}$} & & 32.6 & & 47.3 & & 39.9 \\
\hline Percent residing & n Georgia & & & 16.5 & & 33.7 & & 27.7 \\
\hline
\end{tabular}


of construction work. Construction workers cannot choose the location of large projects at which they are employed, nor are they usually able to move each time a new project is begun. The NEC is of such a size, and the time period over which it will be constructed is so long, that one would expect inmovers to commute much shorter distances; however, the allocation to the Anderson region unfortunately does not reflect such a tendency.

Construction workers also differ from all types of commuters in the size of the counties in which they reside. Only $16.8 \%$ and $19.4 \%$ of in-movers and non-movers, respectively, reside in counties with over 100,000 population (only Greenville and Anderson Counties were over 100,000), while 32\% of 1970 commuters lived in such an area. Rather, a larger percentage of construction workers tended to locate in smaller size counties. This tendency was most pronounced for the in-movers, $47.3 \%$ of whom are projected to live in counties of less than 40,000.

Another characteristic of NEC construction workers of considerable importance to the Anderson Region is the proportion of workers expected to locate in Georgia. While only $16.5 \%$ of 1970 commuters to Anderson County live in Georgia, $33.7 \%$ of the in-movers and $27.7 \%$ of non-movers are projected to live there. There may be some over-estimation of the workers expected to live in Georgia because the method used to calculate distances ignores the extra travel required to reach bridges crossing the lakes on the Savannah River, the boundary between South Carolina and Georgia; thus, distances from locations in Georgia to the NEC site are understated.

Aggregation to the county level is necessary to make a comparison with available census data on commuters, and although considerable detail is lost, such a comparison highlights several characteristics that establish a basis from which additional study may begin.

\section{SUMMARY AND CONCLUSIONS}

To accurately assess the impact of any new industry in a region, the residential location of new workers must be estimated. This need is of considerable importance when a large activity such as the nuclear energy center is anticipated. This paper presents an application of a gravity model designed to estimate future residential patterns of workers at the Anderson County, S. C., Nuclear Energy Center based upon survey data for workers at the Catawba Plant in York County, S. C.

A statistically significant model was obtained using only CCD population and distance to the plant site. The equations estimated reflected the varying importance which in-movers and non-movers attach to the distance and population variables. A broad comparison of the distribution of all commuters with that of construction workers reveals differing locational behavior and indicates characteristics which merit further study.

Further work on the Catawba model particularly with non-movers, might include further testing of weights, which account for variables such as distance 
to population centers of various sizes, unemployment rates, availability of alternative employment, etc. Also, for application to the Anderson region, adjustments to the distance figures, from Georgia counties especially, would be useful.

\section{REFERENCES}

1. Borez, Judith A. The Use of Gravity Models to Distribute Power Plant Construction InMigrants, Oak Ridge, TN, Oak Ridge National Laboratory, December, 1977.

2. Chalmers, James A. "The Role of Spatial Relationships in Assessing the Social and Economic Impacts of Large-Scale Construction Projects", Natural Resources Journal, Vol 17, 1977.

3. Harris, C. D. "The Market as a Factor in the Location of Industry in the United States", Annals of the Association of American Geographers, Vol. 44, No. 5, December, 1954.

4. Henry, Mark S. The Economic-Demographic Impact of a Nuclear Energy Center - A Methodological Discourse and Application to the Anderson County, S. C., Site, Clemson University, Department of Agricultural Economics and Rural Sociology, February, 1980.

5. Hertsgaard, T., et. al. The REAP EconomicDemographic Model - Technical Description (Bismark ND: Regional Environmental Assessment Program), 1977.

6. Hua, Chang-i and Frank Porell. "A Critical Review of the Development of the Gravity Model", International Regional Science Review, Vol. 4, No. 2, 1979.

7. Isard, Walter. Methods of Regional Analyses, Cambridge, MA, MIT Press, 1960.

8. Leholm, Arlen G., et. al. "Economic Impacts of Construction and Operation of Coyote Station \#1 Electrical Generation Plant and Ex- pansion of Coal-Handling Facilities at the Beautal Mane of Knife River Coal Compact", North Dakota State University, Fargo, North Dakota, June, 1977.

9. Murdock, Steve H., James S. Wieland and F. Larry Leistritz. "An Assessment of the Validity of the Gravity Model for Predicting Community Settlement Patterns in Rural Energy-Impacted Areas in the West", Land Economics, Vol. 54, No. 4, 1978.

10. S. C. Employment Security Commission. Commuting Patterns for South Carolina Counties 1970 Census Data. Columbia, S.C., April, 1973.

11. Stouffer, Samuel A. "Intervening Opportunities: A Theory Relating Mobility and Distance", American Sociological Review, Vol. 5, No. 6, December, 1960.

12. Unpublished data from Duke Power Company, Catawba and Cherokee Nuclear Plant Construction Work Forces Survey, 1977 and 1978.

13. Wieland, James S., F. Larry Leistritz, and Steve H. Murdock. "Characteristics and Residential Patterns of Energy-Related Work Forces in the Northern Great Plains", Western Journal of Agricultural Economics, Vol. 4, No. $1,1979$.

14. Wizard Research and Development Group, Inc. "Models and Methodologies for Assessing the Impacts of Energy Development", Washington, D.C., June, 1977. 